\title{
Gadget: An Alternative Learning Media in Developing the TPACK
}

\author{
Choiriyah \\ STKIP Panca Sakti-Jalan Raya Hankam No.54, Jati Rahayu - Bekasi \\ e-mail: ririchalid.13@gmail.com
}

\begin{abstract}
TPACK (Technological Pedagogical Content Knowledge) is a framework for designing a new learning model by combining three main aspects called technology, pedagogy, and ontology. The lack of facilities for technology in the schools may become the problems, as it will support the learning process. This limitation may become a barrier and may influence the activity of teaching and learning holistically. Meanwhile, gadget as the product of technology is ready to use for everyone; by this means, it can be an alternative way in developing learning materials by using TPACK. Games of educative learning such as colors recognition, geometries, and moral stories can be programmed in any gadget. Therefore, this media can be used as an alternative program in the learning model which refers to TPACK. The Purpose of this study is to provide an overview to Early Childhood educators that gadgets can be used as a medium of learning to support TPACK program. The research methodology used is descriptive qualitative.
\end{abstract}

Keywords: $\quad$ TPACK, Gadget, Learning Media

\section{INTRODUCTION}

Knowledge of early childhood education continues to grow, one of which is the concept of teaching in the design of new learning models by combining three main aspects of Technology, pedagogy and content or knowledge materials. The term which came to be known as TPACK (Technological, Pedagogical Content Knowledge) is a framework in the design of current learning models where the rapid advancement of information technology is a necessity that teachers must master to be used as a supporting medium in learning activities.

Learning in early childhood education is presented in an interesting and coherent form so that children are motivated to be able to follow all activities with enthusiasm and motivation in digging their knowledge. In learning activities, it cannot be denied that the methods and learning media have very important roles to achieve optimization of learning outcomes for early childhood. The interest of the child as a learner should be the focus of the educators or facilitators, such as how is the child's learning style, what is his/her hobby and current trends, etc., it must be observed by an educator.

Various interesting media can be used as a magnet in learning, and one of them is gadgets. Technology clearly affects the development of children, because a technology device is a very effective learning media, technological progress can also help the creativity of children, if the empowerment or utilization is offset by an interaction with the environment. Gadget is a small electronic device that has special function. On day to day basis, in the gadgets, something new always comes up by presenting the latest technology that makes human life more practical. These gadgets can be found anywhere; both adults and children often have them. Gadgets that have become the consumption of all ages also make children as their target market, some even become 'gadget freaks' (Muzakki, 2013).

In the approach of TPACK program, technology is needed so that educators/teacher who have limitations in this case can also use gadgets as appropriate technology in order to optimize TPACK learning program approach. Various educative 
programs can be accessed through Google Play in each gadget, so the process of learning can run without constrained by the lack of technology at school.

Gadgets are items that are commonly used everywhere, this allows each educator to use them and apply the technology in learning classes. Limitations possessed by various regions in Indonesia make it possible for each education to at least use this gadget as a technology-based learning media that can support the achievement of the TPACK program. However, there are signal constraints in certain areas that might not have been maximized; this can be a concern for the government to pay attention to all regions in Indonesia in terms of even distribution of technology throughout the corners of the country. Hopefully in the future learning in supporting the TPACK program can continue to be appreciated by both central and local governments for the achievement of better educational goals for all children in Indonesia.

\section{METHOD}

The methodology used in this reasearch is descriptive qualitative, in which the researcher studied in depth about the use of gadgets in an effort to optimize TPACK. Then pair it with various theories related to it. The journal used as a reference in this case is the impact of ICT and Electronic gadget among young children in kindergartens in 2017. In the journal it was said that gadgets have a positive role in developing ICT in children's learning in schools.

In the journal entitled: The Impact of Using Gadgets on Children, the Positive and Negative Impact of Gadgets on Children, it was explained that gadgets do not only have negative impacts that is known by many people, but they also have positive impacts on children, depending on how these gadgets are used and adult assistance around them

\section{RESULT AND DISCUSION}

The approach of TPACK learning program requires the support of technology in its implementation. Theacher should master technology that can support teaching and learning activities in class, so that the learning objectives can be optimally achieved. Learning media which becomes a milestone in TPACK, does not necessarily have to be an expensive technology which is difficult to obtain, because not all schools are able to present the media at school. Therefore the author sees gadgets as one of the latest technology that can be easily accessed by anyone. The rapidly increasing numbers of competing technologies cause the price of the gadgets to be more affordable. Once, a gadget is something luxurious, but now it is no longer the case. Observed from the current reality, it has become commonplace if elementary school children have gadgets as their 'toys' (Panji Ismail, 2013). It is necessary to see that Gadgets can be used as alternative learning media in early childhood learning in order to optimize the approach of TPACK learning program.

\section{Learning Media for Early Childhood}

The learning experience presented with the media is definitely better than the non-media. Moreover, for young children who are still in concrete preoperational stage, every learning should be presented by teacher with various media which are appealing and in accordance with stages of child development.

Media comes from the Latin word "Medius" which means "middle", "intermediary" or "introduction". In Arabic the media means an intermediary or introduction of the sender's message to the recipient of the message. If the media is carrying messages or information that aimed instructional or contain a certain purpose, then it is considered as a medium of learning. The benefits of media in the learning process are to be used as teaching methods and learning media. These two aspects are related. The selection of one method of learning will affect the selection of learning media that will be used. In general, the benefit of learning media is to facilitate the interaction between teachers and students so that learning will be more effective and efficient. But in particular there are some benefits of more detailed instructional media, Kemp and Dayton describe in detail as follows:

1. The delivery of learning materials can be uniformed

2. The learning process becomes more clear and interesting

3. The learning process becomes more interactive

4. Efficiency in time and effort

5. Improve the quality of children's learning outcomes 
6. Media allows the learning process to be done anywhere and anytime

7. Media can foster positive attitude of children to the material and learning process

8. Change the role of teachers to be more positive and productive (Kemp and Dayton, 1985)

Learning media is clearly needed in optimizing the learning process both in the learning of early childhood, adolescents and adults, because with the use of learning media, the process of knowledge input becomes more meaningful especially for children, in the context of concrete preoperative and operational periods. Children will easily catch one learning material with something that impresses them, with supporting images and sounds. So that technology cannot be kept away from our daily lives because we use it in our daily lives, and in its application in the middle of learning at school

Types of learning media

There are many kinds of learning media ranging from the smallest and simple ones to the most sophisticated and expensive media. There are media that are available in the environment and the media must be prepared and designed to support maximum learning. Although learning media has many varieties, but teachers often only use the book as a medium of learning, so that children are bored with the learning process presented. Besides, there are many schools that have utilized the types of media images, OHP, VCD, etc., although they are still rarely used. For certain schools that have limited funds to provide media and learning resources, they can take advantage of gadgets as learning media that also have various functions.

Anderson, 1976 classified the media into 10 groups as follows:

\section{No Media Category Examples in learning}

I Audio

Audio cassettes, radio broadcasts, CDs, telephones

II Printed
Textbooks, modules, brochures, leaflets, pictures
III Audio-Printed

Silent Visual

Projection

V

Silent Visual

Projection

VI Moving Visual

Silent movie

VII

Moving Audio
Visual

Moving audio visual, motion pictures with sounds, VCD, DVD, television, laptop, Tablet, Gadget

VIII Physical Objects

Real objects, model, specimen

IX

Humans and environment

Teachers, librarian, laboratory officer

$\mathrm{X}$ Computer

CAL (computer assisted learning)

CBL (computer-based learning)

In this case the gadget can act as a learning medium to support the TPACK program in schools that still have limitations in technology. And educators as gadget users are expected to be able to apply it in learning easily, among others in broadcasting audio-visual films, educative games applications, displaying various images and stories related to various themes that exist in school learning

The Benefits of Gadgets for Early Childhood

"Gadget is an English term that defines a small electronic device with a variety of special functions "(Osland, 2013). One of the factors that differentiate gadgets with other electronic devices is "novelty". This means that from on a day to day basis, gadgets 
always appear by presenting the latest technology that makes human life more practical.

The benefits of gadgets in education include; 1). We can look for educative games, in the gadget there are also various kinds of educational games that can stimulate children's brain, and this game pattern can be adjusted according to the children's age. This is one of the learning media that will make children feel happy. When children learn only by using the book they will feel bored and saturated very easily. By using the media of learning that we apply through gadgets, it will minimalize boredom, because children do not realize that they are actually learning. 2). Learning technology response, with this all-sophisticated era of course we cannot stem the curiosity of children about various objects around them, one of which is their curiosity on gadgets. Adults must supervise children while they are playing with gadgets, and even make this gadget as a learning medium to support the learning process. 3). we can find innovative educational information. This also will increase knowledge for children by finding the media that can give information and also material to satisfy the knowledge of children. As children learn to play the piano, children learn about volcanoes, learn handicrafts such as origami, kirigami, etc. This can also be a positive activity for mother and child. 4). Training the brain function. Gadgets are useful for children because they have apps for eye and hand coordination. Children's speed when they are learning to use the gadgets is very impressive. They learn to squeeze the keyboard, shifting the touch screen and pressing which particular button functions.

In this case, the gadget is not merely seen as an item that is full of negative impacts on children's development, but the mindset about it can shift slightly that the gadget can also be used and has a variety of positive effects for children both in eyehand-brain coordination, and impact social emotional, depending on how this gadget is used in their lives. It should indeed be the use of gadgets in assisting adults and giving direction to children, so that the desired learning goals are achieved, namely the gadget is used as an alternative learning media in supporting learning programs with TPACK approach.

The Use of Gadgets as Learning Media in The Approach of TPACK Program

Gadget is one of the media that can support TPACK program in learning. The rapid advancement of information technology is a necessity that the teacher must master the technology and then used it as a supporting medium in the learning activities. Some examples of the application of technology in learning are like the ideas offered by NACOL (North American Council for Online Learning), a blended learning model to support learning activities that have been done in the classroom.

In addition to the use of technology as a learning media, in the TPACK framework, pedagogy is an important aspect that needs to be addressed in the learning activities. Pedagogical aspect is not only about how to develop the arts in teaching or design the completeness of process instruments and assessment in learning, but also required to understand students psychologically and biologically. In this pedagogical thinking there is an emphasis, that a successful teacher is not a teacher who can only make his students smart like him, but more than that, that is a teacher who can successfully help students find themselves. Interest in talent as well as the character of the learner should ultimately be understood by a teacher.

At the TPACK framework, there is a complex interplay of three primary content of knowledge: Content (CK), Pedagogy (PK), and Technology (TK). The TPACK approach goes beyond these three knowledge bases in isolation. The TPACK framework goes much further in the form of Pedagogical Content Knowledge (PCK), Technological Content Knowledge (TCK), Technological Pedagogical Knowledge (TPK) and Technological Pedagogical Content Knowledge (TPACK).

Effective technology integration for pedagogy around specific subject matter requires developing sensitivity to the dynamic, transactional relationship between these components of knowledge situated in unique contexts, Individual teachers, grade-level, school-spescific factors demographics, culture, and other factors ensure that every situation is unique, and no single combination of content, technology, and pedagogy will apply for every teacher, every course or every view of teaching.

As educators know, teaching is a complicated practice that requires an interweaving of many kinds of specialized knowledge. In this way, teaching is an example of an ill-structured discipline, requiring teachers to apply complex knowledge structures across different cases and contexts (Mishra, Spiro, \& Feltovich, 1996; Spiro \& Jehng, 1990). Teachers 
practice their craft in highly complex, dynamic classroom contexts (Leinhardt \& Greeno, 1986) that require them constantly to shift and evolve their understanding. Thus, effective teaching depends on flexible access to rich, well-organized and integrated knowledge from different domains (Glaser,1984; Putnam \& Borko, 2000; Shulman, 1986, 1987), including knowledge of student thinking and learning, knowledge of subject matter, and increasingly, knowledge of technology.

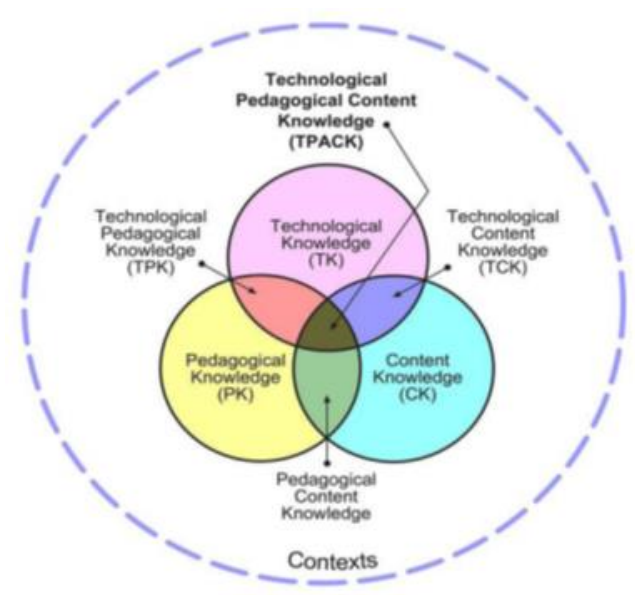

Content knowledge in the TPACK framework is the basic element that a teacher must possess according to his or her scientific discipline. This problem needs direct intervention of the government to be more serious again in making more stringent regulations related to professional teachers. In fact, there are many professional teachers (certified) who enter the wrong field (mismatch). For example, there is an Early Childhood Education teacher with office administration degree, or kindergarten teachers who graduate from Chemistry Education, and so on. To improve the content knowledge, educational background is very important. In addition, it is not enough for teachers to only rely on textbooks alone. They need to be supported by updating the latest information related scientific field published by the institutions of trusted research journals.

Finally, TPACK is a framework for researchers and teacher in an effort to package and develop learning models to achieve learning objectives through a better process so that the learning process gets the right touch and the children can obtain a well-acquired knowledge from teacher who also understand correctly about the ins and outs of early childhood education. And gadgets can be used as alternative learning media to support this. So wherever the school is, technology can still be touched by various groups through the use of this gadget as an alternative learning media in supporting the TPACK approach program

\section{CONCLUSION}

Gadgets as objects that are commonly seen and used in daily life can be used as alternative learning media to support learning programs with the TPACK approach. The TPACK (Technological, Pedadogical, Content Knowledge) is a framework (framework) in designing new learning models by combining three main aspects, namely technology, pedagogy and knowledge material. In practice in the field, the facilitators often find it difficult and hampered due to the lack of supporting technology facilities in their schools. The limitations of this infrastructure often become an obstacle in optimizing holistic learning for early childhood. While the gadget as a ready-to-use technology and anyone can use it can be an alternative in developing learning with this TPACK. Through the use of media gadgets, it can be filled with educative games features, learning content for AUD such as color recognition, geometric shapes, stories and recollections for children's moral development. Gadgets that have been stamped as destroying child morality and child discipline, we can use as an alternative media in a learning model that refers to TPACK

\section{REFERENCES}

[1] Anonymous.(2013)."Anak dan Gadget: Yang Penting Aturan Main." http://www.tabloidnakita.com/read/1/anak-dan-gadget-yangpenting-aturan-main. (accessed 5 Desember 2013)

[2]

[3] Cvano,Osland.(2013).'Pengertian Gadget".http ://mencobacariduit.blogpot.com/2013/09/penger tian-gadget.html / 2013/ (accessed 17 agustus 2013)

[4]

[5]

[6] Departemen Pendidikan Nasional, Kamus Besar Bahasa Indonesia Pusat Bahasa, Gramedia Pustaka Utama, Indonesia, 2008, hlm. 862

[8] Koehler, M. J., \& Mishra, P.(2009), What is technological pedagogical content knowledge? Contemporary Issues in Technology and Teacher Education, 9(1), 60-70

[9] 
[10] Lexy J. Moleong, Metodologi Penelitian Kualitatif, Remaja Rosdakarya, Bandung, 2009.

[11]

[12] Mishra, P., \& Koehler, M. J. (2006), Technological Pedagogical Content Knowledge; A framework for teacher knowledge, Teachers College Record, 108(6),1017-1054, doi: 10.1111/j.1467-9620,2006,00684.x.

[14] Metta. (2013).'Kapan waktu tepat memeperkenalkan gadget pada anak".http://bidanku.com/kapan-waktu-tepatmemperkenalkan-gadget-pada-anak. (accessed 5 Desember 2013)
[15] Muzakky, akhmad.(2013).'Pengaruh penggunaan Gadget yang berlebihan terhadap perkembangan anak"
http://blog.ub.ac.id/akhmadmuzakky/2013/03/1 anak" 4/pengaruh-penggunaan-gadget-yangberlebihan-terhadap-perkembangan-anak. (accessed 5 Desember 2013)

[16]

[17] Shulman, I. S. (1986), Those who understand : Knowledge growth in teaching. Educational Reasearcher, 15(2), 4-14.

[18]

[19] Suwarna dkk (2006), Pengajaran Mikro; Pendekatan Praktis Menyiapkan Pendidik Profesional, Yogyakarta: Tiara Wacana, hal.118 